\title{
Influence of Extracurricular Services on Students' Academic Achievement in Secondary Schools in Kwara State: A Qualitative Approach
}

\author{
Yusuf Suleiman', Zahyah Bt Hanafi ${ }^{2}$, Muhajir Tanslikhan ${ }^{3}$ \\ ${ }^{1}$ Department of Educational Management and Counselling, Al-Hikmah University, Nigeria \\ ${ }^{2}$ Faculty of Education, City University Kuala Lumpur, Malaysia \\ ${ }^{3}$ Faculty of Education, Universitas Dr. Soetomo, Indonesia
}

DOI: 10.23917/ijolae.v1i2.7766

Received: January $1^{\text {st }}, 2019$. Revised: January $14^{\text {th }}, 2019$. Accepted: June $19^{\text {th }} .2019$

Available Online: June $20^{\text {th }}, 2019$. Published Regulary: July $1^{\text {st }}, 2019$

\begin{abstract}
Extracurricular services are regarded as essential services in school system. Studies suggest that access to the services lead to students' academic success. Literature shows that the use of qualitative approach to investigate extracurricular services is limited. In view of the foregoing, this study examined the perceived influence of extracurricular services on students' academic achievement in secondary schools. Twenty (20) principals were selected from the three senatorial districts of Kwara State using stratified, purposive and convenience sampling techniques. Instruments used include interview and observation methods to collect relevant data from the participants. Specifically, observation method was used to complement findings from interview. Our findings reveal that extracurricular services influenced students' academic achievement. Our findings revealed also that inadequate availability of extracurricular facilities and personnel are the factors militating against effective provision of extracurricular services. This study recommends that adequate extracurricular facilities (football pitch, volleyball court, hall for social activities, etc.) should be available in schools. Lastly, adequate extracurricular services personnel should be deployed to schools to ensure active participation of students in various activities.
\end{abstract}

Keywords: extracurricular services, academic achievement, secondary schools, qualitative approach.

Corresponding Author:

Department of Educational Management and Counselling, Al-Hikmah University, Nigeria

e-mail :yusufsuleiman@alhikmah.edu.ng

\section{Introduction}

Extracurricular services are the services provided in school which students participate apart from the necessity of gaining a certificate. These extracurricular services (i.e. sports and social activities) provide additional advantages for students to manage stress and to grow the level of their skills, experiences, and functionality (Adeyemo, 2010; Ensturk, Demir, Yilmaz \& Ilhan, 2016). Extracurricular activities experience has become an important component of students' school life as many students today engage in various activities that they cherish. Different activities, in which students engage, both inside and outside the school environ-ment, are among the numerous situations or agents that can have an influence on these con-cepts. The foregoing situation has given rise in our society to an almost massive involvement in after-school activities. Activities for supporting, complementing and strengthening not only the student's school 
success, but also their personal development and other aspects such as health, values, leisure, etc (Mahoney, Cairos \&Farwer, 2003).

According to Moriana, Alós, Alcalá, Pino, Herruzo and Ruiz (2006), Schools invested substantial resources on extracurricular services and they are expected to provide a wide range of these services to provide a balanced education. Extracurricular activities provided in school are often categorized into two welldifferentiated types: extra-scholastic (outside the school program) and extracurricular (complementary activities carried on within the school setting, and generally under school auspices). A reasonable number of quantitative studies suggest that availability of extracurricular activities in school is associated with an improved educational level, higher aspirations, more interpersonal competencies and a better attention level (Pitts, 2010; Mahoney, Cairos \& Farwer, 2003), increased critical thinking and personal and social maturity (Adeyemo, 2010; Kim \& So, 2012), and generally speaking, with great benefits that serve to bridge school activities with those performed outside the academic setting (Noam, Biancarosa \& Dechausay, 2003). Pitts (2010) and Trail (2002) found that extracurricular activities increased the academic success of individuals and make contribution to the character guidance (Prayitno, Ngalim, Sutopo, Rohmadi, \& Yuniawan, 2018). Also, literature shows that little attention is given to qualitative approach in investigating the impact of extracurricular services on students' success. The one conducted by Esenturk et al., (2016) limited their study to evaluation of extracurricular activities in school without examine its impact on students' academic achievement, thus suggesting that qualitative studies are yet to be fully used exhausted.

In view of the foregoing, the focus of the present study is to investigate the perceived influence of extracurricular services on students' academic achievement in secondary schools in Kwara State, Nigeria via a qualitatihve approach with a view of gaining a better understanding of the study phenomenon.

\section{Method}

The research design for this study is qualitative method. The reason for using qualitative method is to gain a better understanding of the study phenomenon, as suggested by Creswell (2009). Another reason for is that it helps to get the richness of the study context. The study population consists of entire principals of both public and private secondary schools in Kwara State, Nigeria. In order to select draw participants from the population, we used three sam-pling techniques. Firstly, stratified sampling technique was used to group all schools into three senatorial districts (kwara central, kwara south and kwara north) with its 16 local government. Secondly, purposive and convenience sampling techniques were employed to select 20 princi-pals from twenty secondary schools from the three senatorial districts (Ary, Jacobs and Razavier, 1997). The reason for using principals is that they have broad knowledge of activities in their domain. Since they are the one responsible for the implementation of school curricu-lum, it is expected that adequate information regarding extracurricular services can be gotten from them with a view to using it for research purpose. Below is Table 1 showing the three senatorial districts and its local government in Kwara State, Nigeria. Also, Figure 2 depicts the map of Kwara State and where its 16 local governments are located. 
Table 1. Three Senatorial Districts and Its 16 Local Government in Kwara State

\begin{tabular}{ll}
\hline & Kwara South Senatorial District \\
\hline 1 & Ifelodun \\
2 & Irepodun \\
3 & Ekiti \\
4 & Offa \\
5 & Oyun \\
6 & Isin \\
7 & Oke-Ero \\
\hline & Kwara Central Senatorial District \\
\hline 8 & Asa \\
9 & Ilorin South \\
10 & Ilorin West \\
11 & Ilorin East \\
\hline \multicolumn{2}{|c}{ Kwara North Senatorial District } \\
\hline 12 & Baruteen \\
13 & Kaima \\
15 & Patigi \\
16 & Edu \\
\hline
\end{tabular}

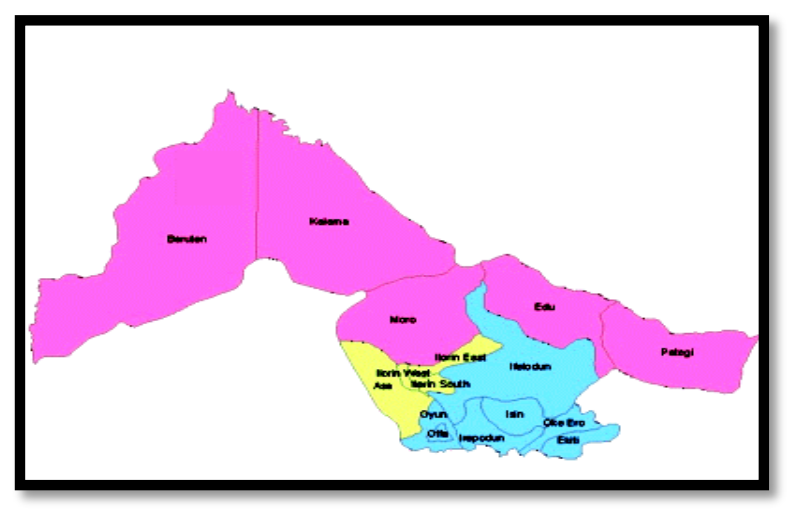

Figure 1. Map of Kwara State showing 16 local governments are located

\section{a. Study Instrument}

An instrument tagged "Interview Guide on Extracurricular Services (IGES)" developed by researchers was used to collect relevant data for the study. Some of the items in the interview guide were adapted from previous studies (e.g.Mestapeltan \& Pukkinin, 2014; McCaughn, 1999) who investigated the influence of extracurricular services on students' academic achievement via a quantitative approach. Two reasons justify the use of interview for the study. Firstly, interview covers essential information that can be used to elicit relevant information from the interviewees. Secondly, interview helps get in-depth views which a conclusion can be drawn from it (Gay \& Aisaran, 2000). In addition to the use of interview, standard observational checklist adapted from previous studies, was used to collect and assess extracurricular services in the visited schools. The observation was used to complement the findings from interviews conducted (Creswell, 2009).

\section{b. Validity and Reliability of the Instrument}

Firstly, in order to ensure validity of the instrument, experts in the field of the study assisted to ensure that the items contained in interview guide and observational checklist are capable of eliciting relevant data for the study. The also ensured that those items are relevant to the study research questions. All the corrections made by the experts were effected as directed. By this measure, both 
the face and content validity of the instrument were assured (Creswell, 2009). Secondly, in order to ensure reliability of the instrument, we carried out a reliability test so as to determine the consistency of the adapted instrument. To achieve this, pilot study involving 2 principals were drawn from 2 secondary schools outside the schools used for the main study.

\section{c. Ethical Consideration}

This study was conscious of ethical consideration because it is one of the fundamental issues in qualitative research (Creswell, 2009). In order to achieve it, an ethical approval to investigate the perceived influence of extracurricular services on students' academic achievement in secondary schools was secured. Firstly, an introduction letter was obtained at Ahwang Had Salleh Graduate School of Arts and Sciences, Universiti Utara Malaysia explaining the nature and purpose of the study. Secondly, a written informed consent was secured from the principals and participation was voluntary, nobody was forced to participate in the study. Thirdly, the interviews were conducted in a setting that ensured privacy and confidentiality (Ary, Jacobs and Razavier, 1997; Creswell, 2009).

\section{d. Data Collection Procedure}

In this study, data were collected with the help of two research assistants, who ensured the recording of the interviews. At least, 30 minutes each was used to conduct interview for the participants (principals) selected for the study. The interviews conducted lasted for 3 months. Specifically, ten principals were interviewed in one month; five principals were interviewed in the second month while the remaining five principals were interviewed in the third month. Materials used to collect data include digital audio tape, iPad phone, camera, laptop, biro, pencil, eraser, exercise book and jotter (Creswell, 2009).

It is imperative to provide a background of informants in qualitative research, this is also applicable in quantitative research as well. The essence of providing the profile of informants is to gain a better understanding of the informants based on their unique or characteristic that formed their personality. Another reason for reporting the profile of is to exhibit transparency in research, however, as explained earlier, twenty informants (schools' principals) formed the total sample size for the study (Creswell, 2009). The profile of the informants is displayed below:

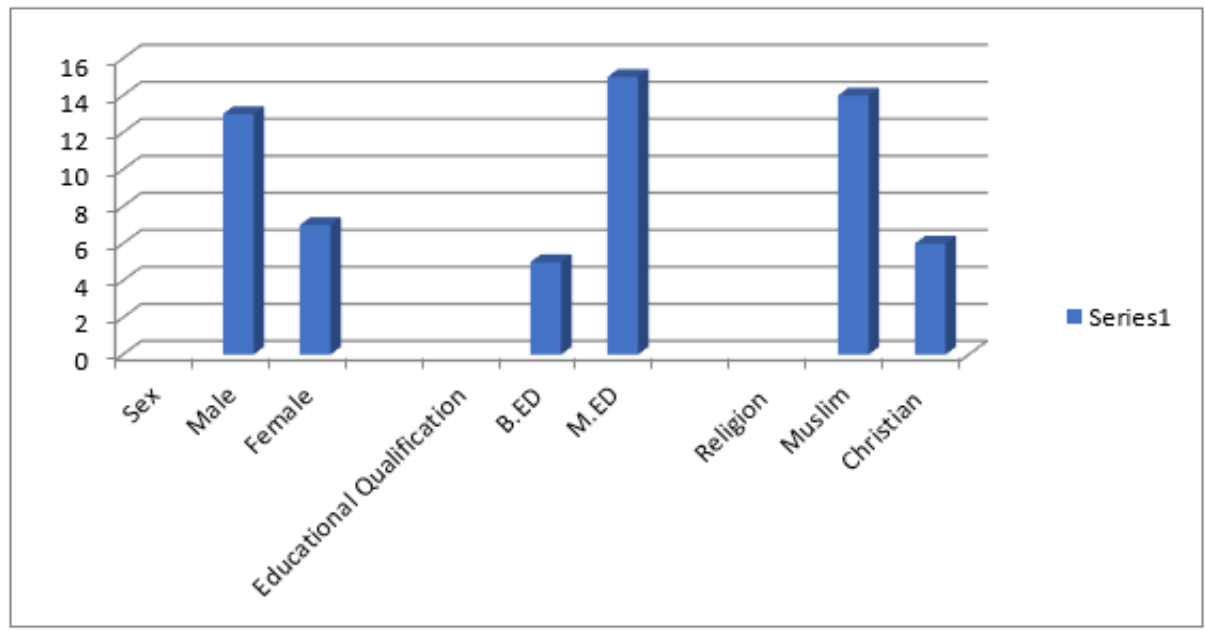

Figure 2. Profile of The Informants

Based on sex, it shows that that the majority of the informants are males with 13 informants while seven informants are females. The 13 informants (males) account for $65 \%$; while seven informants (females) ac- count for $35 \%$. Regarding age, it shows that majority of the informants' age (15 informants) is 50 years and above, which represents $75 \%$, while five informants' age is less than 50years, which represent $25 \%$. Also, 
figure 2 revealed that most of the informants possessed Masters' Degree in Education (M.Ed.). Fifteen (15) of the informants acquired a masters while the remaining informants (5) possessed Bachelor Degree in Education (B.Ed.). The 15 informants account for $75 \%$ of the sample size while five informants account for $25 \%$ of the sample size. The implication of this is that the majority of the interviewed principals were educated, which helped to get accurate information needed for the study. Lastly, regarding religion, the study shows that the majority of the informants are Muslims (14) while the remaining informants are Christians (6). The 14 informants represent $70 \%$ of the informants while seven informants represent $30 \%$.

\section{e. Data Transcription and Thematic Coding}

After successful data collection, the collected data were transcribed with the use of laptop and hear piece. The transcription produced 20 pages. The transcribed data was subsequently coded in line with the study research questions. The data coding produced three (3) main themes and eight (8) subthemes. The three main themes are: (1) issues on extracurricular services; (2) factors affecting provision of extracurricular services; (3) ways of ensuring effective extracurricular services (Yildrim \& Simsek, 2013). Table 2 below shows detailed main and subthemes of the study based on research questions.

Table 2. Main and Sub-themes Based on Coding

\begin{tabular}{ll}
\hline Main Theme & 3 \\
\hline Number of theme & 8 \\
Number of sub-theme & 4 \\
\hline Theme One (Issues on extracurricular services ) & 2 \\
\hline Number of sub-theme & 2 \\
\hline Theme Two (Factors affecting provision of extracurricular services) & 2 \\
\hline Number of sub-theme & 19 \\
\hline Theme Three (Ways of ensuring effective extracurricular services) \\
\hline Number of sub-themes
\end{tabular}

\section{Result and Discussion}

a. The contemporary issues on extracurricular services in school

Nowadays, no student would say no to active participation in extracurricular services. It is one of the oldest and main services in the school system. Ekeke (2014) asserts that a school without service is in- complete because of its unique importance. In this study, an attempt was made to know the meaning of extracurricular services in the education system. Expectedly, quite number of principals used for the study gave comprehensive responses to what extracurricular services mean in the education system. Start with, some informants explained that: 
"Extracurricular services are the services for the development of mind and body through physical and social activities. Extracurricular services can be defined as the services meant for students to engage in the school. Extracurricular services are the services provided for students outside the classroom learning. It is an outstanding service in the school system." (Informants 1, 4, 8, and 14).

In support of the statements above on the meaning of extracurricular services, informants 9, 6 and 17 expressed that:

"Extracurricular activity is the training of mind and body through physical and social activities. This is meant to keep the mind and soul of students together. It is often called curricular activities. Extracurricular services are meant for students to develop themselves academical$l y$, physically, socially and emotionally. These services are done outside the classroom. It is an indispensable service in the school."

The above responses show the level of what extracurricular services are all about, this agrees with the study of Ekeke (2014) who submit that extracurricular forms cocurricular activities in the school system. He explained that there was a paucity of research in this area, sadly, most of the study conducted mostly focused on tertiary institutions. He sees extracurricular activities as the activities that students embarked on with a view to developing in them the cognitive, affective and psychomotor domains of the learner. Informants 2, 6, 8, and 18 offered their opinions on the meaning of extracurricular services, they explained:

"Extracurricular services can be defined as the services that are provided for the physical, social and emotional development of students. Extracurricular activities are the activities that are necessary for the development of students in the school. It is also known as co-curricular activities as enshrined in national policy on education. It is a service provided to give students a sense of belonging. Extracurricular activities are vital. When we talk about extracurricular activities, it can be defined as sporting events and debate engagements meant for the students. These activities widen the horizon of the students."

Furthermore, informants 12, 20, and 19 expressed that:

"Extracurricular services refer to activities that students engage in outside the classroom. It is a valuable service that is vital to the development of students. Extracurricular services are services for the social and physical development of the students. These are services that are meant to develop students physically and emotionally. Having extracurricular services in the school is imperative. Extracurricular activities are crucial for the academic development of the students. It is sometimes called cocurricular activities. It should be provided."

Explaining more on the meaning of extracurricular activities, Ohienuran (2008) explains that efforts should be made to understand more of what extracurricular activities stand for by all the stakeholders in the education sector. In the light of this, informants 3,10,11, and 15 asserted that:

"Extracurricular services mean the services provided for the benefit of the students. It is a vital service in the school system. It develops them physically, socially and emotionally. It covers the affective, cognitive and psychomotor learning of the student. It is also called co-curricular services. They are services 
meant for the enjoyment of students in school. It is a service that students participate to for their overall development. Lastly, extracurricular services are the services provided for students outside the classroom learning. It is an outstanding service in the school system."

In synopsis, it is understood that the majority of the informants has knowledge of what extracurricular services meant, which is good for the promotion and development of the services in their schools. It is safe to say that understanding the meaning of the service by the informants is essential to know what kind of extracurricular services they have, whether the services are provided, and knowing the importance of extracurricular services in secondary schools in Kwara State.

Researchers have classified extracurricular activities to be formal and informal activities. They see formal extracurricular activities as moderately structured like to participate in sporting events (i.e. Football, basketball, volleyball, table tennis, etc.) and social activities (debates, quiz competitions, etc.) (Afiah Binti Sheikh Ismail, 2019). Informal activities refer to less structured activities, which has to do with watching television, listening to music, etc. (Fujita, 2006). Some studies in the literature opined that the former (structured activities) are mostly prominent in the activities of students in the school while the latter (unstructured activities) are mostly performed at home (Ekeke, 2014; Fujita, 2006). However, this study empirically supports the structured activities which are known mostly in the school system. Thus, it is evident in this study that most of the principals expressed the nature of extracurricular services in their schools.

For example, informant 8 explained that "... well, we have various types of extracurricular services in our school. We have sports facilities which include a football pitch, table tennis, badminton, etc. We also participate in quiz competitions, debates and other events that are of benefit to the students". Informant 19 said that "... we have various facilities such as a football pitch, table tennis, relay race, etc. We also allow our students to participate in social events such as debates, quiz, religious and other competitions from time to time. This has helped to develop our students mentally, spiritually, and physically."

The views of the informants show that the nature of the extracurricular services includes student participation in sports activities and debate competitions. Fujita (2006) opined that numerous extracurricular activities that are embedded in the school have proven to be of great importance to students. Activities in sports and other related activities are common in schools. To know more about the nature of extracurricular activities that applies to secondary schools in this study, informant 14 asserted that “... our school engages in various activities such as football, volleyball, table tennis, etc. We also engage in social club activities like quiz, debates, etc." Informant 18 also bares his mind that "... our school participates in events such as football, volleyball, basketball, table tennis, relay race and other sports activities... Also, we participate in the quiz, debates and other social events which help to develop students academically, socially and physically... All these are part and parcel of the activities we provided for students in our school". Specifically, informant 17 expressed that "... we have sports facilities that our students use for their physical development. Facilities such as a football pitch, table tennis, basketball court, etc. Our students participate in social activities such as debate, quiz, religious and other competitions for their development". 
In the same vein, informant 20 , who is also in support of other informants on the nature of extracurricular activities in his school, said that "... we have sports facilities such as a football pitch, volleyball, table tennis, basketball, etc. Our students also engage in debate, quiz and other social activities". Similarly, an informant described the nature of extracurricular activities in his school, he said:

"Our school has been involved in various extracurricular activities. We have a football pitch, table tennis, etc. Regarding social activities, our students do participate in debate and quiz competitions and another form of social events for their development. We do teach students in the area of entrepreneurship for the purpose of making them self-reliance after their graduation." (Informant 5).

According to informants 7 and 4, they explained that:

"We have various extracurricular activities lined up for our students in their development. We have a football pitch, volleyball, table tennis, etc. Our students engage in both social and physical activities in school. These are provided for students' use. Also, students in this school participate in quiz competitions, debates, social club, and religion activities. All those above are provided for students in school." (Informants 4 and 7).

Informants 13 and 15 also expressed that:

In our school, we have various sporting activities. We have a football pitch, table tennis, volleyball court, etc. Our students participate in sporting events from time to time. Also, they participate in social activities such as quiz, debates, and religious activities for their development. We have won many awards in sports and quiz and debate competitions."
Furthermore, informants 1, 6, 9 and 10 admitted that:

"We have a series of activities for our students in this school. We participate in the quiz, debate, and social club, religious and other competitions for the development of our students. Also, we have a football pitch, table tennis and other sporting facilities which our students engage in. We allocate Wednesday as extracurricular activities for our students. Our students participate in football, table tennis, relay race, volleyball, debates, quiz competitions, social club, etc. These activities are meant for the overall development of students."

Also, informant 3 opined that:

"We have a variety of facilities for students in this school; we have a football pitch, handball pitch table tennis, badminton, and these are meant for sporting activities. When we talk about social events, our students involve in quiz competitions, debates, and excursions. Our students do well in these mentioned activities as you can see some medals won by our school."

In support, informant 16 describes the nature of extracurricular activities that are applicable in her school, she said"... our students actively participate in both sports and quiz competitions and won trophies. We have a football pitch, table tennis, etc. for students to make use of at break time. Also, they go for debates and quiz competitions within and outside the school". Lastly, informant 2 expressed that:

"We have a variety of facilities for students in this school; we have a football pitch, handball pitch table tennis, badminton, and these are meant for sporting activities. When we talk about social events, our students involve in quiz com- 
petitions, debates, and excursions. Our students do well in these mentioned activities as you can see some medals won by our school.

In view of the foregoing, this study found that the nature of extracurricular ser- vices in secondary schools in Kwara state is similar. Also, our observation on the nature of extracurricular services in secondary schools corroborates the interviews conducted. Table below shows the nature of extracurricular services in schools.

Table 3. Observation on nature of library services in selected secondary schools

\begin{tabular}{cc}
\hline S/N & Nature of library services \\
\hline $\mathbf{1}$ & Football \\
$\mathbf{2}$ & Volleyball \\
$\mathbf{3}$ & Basketball, \\
$\mathbf{4}$ & Badminton \\
$\mathbf{5}$ & Table Tennis \\
$\mathbf{6}$ & Long Jump \\
$\mathbf{7}$ & Handball \\
$\mathbf{8}$ & Relay Race \\
$\mathbf{9}$ & Social Club \\
$\mathbf{1 0}$ & Quiz Competition \\
\hline
\end{tabular}

Provision of extracurricular services in the school is often said to be an essential that could influence the academic performance of students in the school system. Time for extracurricular services helps students or learners on how to make use of their leisure time more wisely and upsurge their intellectual acumen so that they can function well as leaders as well as members of a group (Manebete and Duwa (2015). Nevertheless, extracurricular activities are very popular in Nigerian schools because of its importance. However, the interview conducted on whether extracurricular service is provided for secondary school students or not was the question that was thrown to principals-in-charge of the schools. The responses got from the principals confirmed that extracurricular service is provided for students.

To start with, informants $12,16,17$, and 19 admitted that “... Extracurricular services are well provided for students as far as am concerned. It should be provided for students in schools because of its importance". Informants 3, 5, 7, and 9 explained that "... Extracurricular activities are well provided for students in this school. Extracurricular services should be provided in schools". Specifically, informant 2 expressed his views on the reality of extracurricular services for students, he said:

"Students do involve in extracurricular activities because that is the only way to enjoy themselves outside the classroom activities. Our students participate actively in extracurricular activities which are good for their development. Extracurricular services should be provided from time to time for the overall evolution of the school. Extracurricular service is one of essential services in the school."

The above responses show that extracurricular services are still alive in secondary schools in Kwara State, Nigeria, despite the findings as reported in the literature. Manebete and Duwa (2015) opined that the availability of the services immensely contributes to social, character and physical development as well as for mental and healthy growth, which will, in turn, affects their academic performance positively. In support of this, 
informants $6,8,11,13$ and 14 were of the view that "... Totally, extracurricular are well provided for students in this school as far as am concerned. It should be provided; it is an integral part of the school system. It should be provided in the school. They are imperative. We provide these services for students". Also, informants 1, 4, 15 and 20 said that:

"It should be offered in the school because the service is necessary for the development of the students. Extracurricular services should be provided for students in schools because it is vital for their growth and development.

\section{b. Perceived influence of extracurricular} services on students' academic achievement

The extant literature has shown that students who actively participate in extracurricular activities tend to have good grades in their examinations because they manage time, strive for excellence, and relieve stress in doing things. Besides, extracurricular activities that are well-grounded in the school programs positively have an impact on students' achievement (Ekeke, 2014). However, given those above about the importance of extracurricular activities in the school system, this study is totally in support of it as the interviews conducted shows clearly the significance of extracurricular activities for students in secondary schools. Meanwhile, quite a reasonable number of informants attested to this and bared their minds on how their students' participation in extracurricular activities improves their students' academic achievement. For instance, according to the statements emanating from informants 1 and 11, they said that:

"One of the important of extracurricular services is that it prepares students for future challenges. It helps students to explore skills they have. It makes them develop socially. It helps them to be physically fit. It helps them to put into practice what they have learnt in the classroom. Finally, extracurricular activities improved students' academic achievements in our schools."

In buttressing the above on the importance of extracurricular activities in the school system, some of the informants believed that students who participate in it stand to benefit more than those that do not participate, informants 5, 9, and 10 said that:

"The importance of extracurricular services is to bring out talents in them. It fosters unity among the students. It is also to promote friendship among the students. It helps them to gain exposure. It contributes to develop students emotionally, physically and socially. It helps students in their academic careers. It prepares students for future challenges."

Similarly, informants 6, 12, and 19 expressed that:

"It assists in enhancing students' academic performance. It develops students emotionally, physically and mentally. It develops students socially. These are some of the importance of extracurricular services in the school system. It creates friendship among students within and outside the school."

Some informants are of the view that the importance of extracurricular activities is beyond the known academic performance; the importance covers both the visible and invisible. They said:

"It develops physical development of students. It fosters unity among students. It enhances the academic performance of students. It creates friendship among students. It helps students spiritually. It helps students socially, physically and psychologically. It also helps in the men- 
tal development of the students." (Informant 8, 15 and 18).

Informants 4, 13, 14 and 20 justifies the inclusion of extracurricular activities in the school programmes, they expressed that:

"They are crucial to the attainment of the school's goals and objective. It helps to promote competition among students. It develops students physically, emotionally, spiritually, and socially. It makes the students fit. It fosters unity amongst students. It is an essential service in the school system."

Furthermore, another informant who is also in support of other informants' submissions on the importance of extracurricular, he said that:

"The importance of extracurricular activities is enormous. Firstly, It brings mental alerting. It promotes friendship amongst the students, and it gives room for competition. Extracurricular is a tool for community development as well as the state and country development because it is through these events that bring development to the society." (Informant 2)

Informants 17 said that "... it helps to sharpen the emotional and social development of students. It contributes to develop students physically. It enhances the academic performance". Informant 3 also expressed that “... for mental alertness.... for social development of the students... and for the psychological development of students". Lastly, informant 16 opined that “... it enhances the academic performance of students... It fosters unity among students and creates competition among students."

\section{c. Factors affecting provision of extra- curricular services in school}

Based on the interviews conducted in the study, it is evident that majority of the informants concurred that non/inadequate availability of extracurricular services inhibits effective provision of extracurricular services in secondary schools. According to informants 2, 3, 6, 7 and 8, they asserted that "... our schools doesn't have enough sports (i.e. football, volleyball basketball etc.) equipment which students can use for extracurricular activities". In support of the foregoing, informants 1, 9, 10, 11, 12 and 19 expressed that "...Due to population explosion in our schools, inadequate sports facilities sometimes stop our students from participating in sports (volleyball, basketball, gymnastic, handball, etc.) that are available in our schools". In the same vein, informants 5, 18, 16 and 17 said "...Inadequate availability of extracurricular facilities is a serious challenge in our schools. For instance, in sports, the facilities we have cannot accommodate large number of students at a time".

Table 4. Observation on availability of extracurricular facilities in 20 selected schools

\begin{tabular}{llll}
\hline S/N & \multicolumn{1}{c}{$\begin{array}{c}\text { Extracurricular Facilities in 20 } \\
\text { selected schools }\end{array}$} & Available & Not available \\
\hline $\mathbf{1}$ & Football pitch & Available in 20 schools & \\
$\mathbf{2}$ & Volleyball court & Available in 8 schools & Not available in 12 schools \\
$\mathbf{3}$ & Badminton court & Available in 4 schools & Not available in 16 schools \\
$\mathbf{5}$ & Table Tennis & Available in 20 schools & \\
$\mathbf{6}$ & Gymnastics & Available in 2 schools & Not available in 18 schools
\end{tabular}




\begin{tabular}{llll}
\hline S/N & $\begin{array}{c}\text { Extracurricular Facilities in 20 } \\
\text { selected schools }\end{array}$ & Available & Not available \\
\hline $\mathbf{7}$ & Hall for social events & Available in 8 schools & Not available in 12 schools \\
$\mathbf{8}$ & $\begin{array}{l}\text { Mosque and church for religious } \\
\text { activities }\end{array}$ & Available in 11 schools & Not available in 9 schools
\end{tabular}

\section{d. Non/inadequate availability of extra- curricular services personnel}

Interviews conducted in this study confirmed that non/inadequate availability of extracurricular services personnel hinders effective provision of extracurricular services in secondary schools. According to informants 1, 4, 7, 9 and 12, they opined "Personnel in charge of extracurricular activities in our schools are not enough". In the same vein, informants $1,5,8,11$ and 20 expressed thus "Due to lack of personnel, students are restricted to certain activities in our schools". Similarly, informants 8, 14, 15, 16 opined that "We have few people that are in charge of sports and other related activities in our schools". Lastly, the opinion of informants 2 and 9 concurred with the submissions of other informants given earlier, they opined that "To be candid, we don't have adequate personnel to guide students who engage in various activities such as debate, football, quiz completion, volleyball, basketball, handball, badminton, etc."

Table 5. Observation on extracurricular services personnel in 20 selected secondary schools

\begin{tabular}{cccc}
\hline School & $\begin{array}{c}\text { Number of staff available for } \\
\text { sports activities (i.e. football, } \\
\text { volleyball, table tennis, etc.) }\end{array}$ & $\begin{array}{c}\text { Number of staff availa- } \\
\text { ble for other activities } \\
\text { (i.e. quiz competition, } \\
\text { debate, etc.) }\end{array}$ & $\begin{array}{c}\text { Total number of } \\
\text { staff for extracur- } \\
\text { ricular services in } \\
\text { school }\end{array}$ \\
\hline School A & 4 & 6 & 10 \\
School B & 5 & 8 & 13 \\
School C & 5 & 11 & 16 \\
School D & 7 & 10 & 17 \\
School E & 5 & 9 & 14 \\
School F & 4 & 11 & 15 \\
School G & 4 & 6 & 10 \\
School H & 3 & 5 & 8 \\
School I & 5 & 7 & 12 \\
School J & 2 & 6 & 8 \\
School K & 11 & 15 & 26 \\
School L & 10 & 12 & 22 \\
School M & 4 & 7 & 11 \\
School N & 3 & 5 & 8 \\
School O & 2 & 5 & 7 \\
School P & 6 & 9 & 15 \\
School Q & 2 & 7 & 9 \\
School R & 4 & 8 & 12 \\
School S & 5 & 10 & 15 \\
School T & 3 & 9 & 12 \\
\hline
\end{tabular}

Note: Schools with 20 personnel is considered as adequate while schools with less than 20 personnel is considered as inadequate

\section{e. Adequate provision of extracurricu- lar facilities}

Interviews conducted indicated that majority of the informants opined that ade- quate provision of extracurricular facilities will increase students' participation in extracurricular activities in secondary schools. Informants $1,3,6,11,13$ and 14 said: 
"In order to encourage students to participate in extracurricular activities in school, basic extracurricular facilities (such as football pitch, basketball court, volleyball court, badminton court, etc.) should be available for students to use. In the same vein, relevant equipment related to the mentioned facilities should be available in large number so that students who are interested will be able to use it".

Informants 2, 4, 5, 8, 9 and 12 expressed that "Extracurricular facilities in schools are needed to entice students for them to partake in various social activities". Similarly, informants 7, 10, 15, 18 and 20 opined that "Since sports remain the major extracurricular activities that students engage in, sports facilities should be adequately provided so that students can be encouraged to use it". According to informants 6,16 , and 17 :

"Students engagement in extracurricular activities largely depends on availability of facilities in the school. To this end, adequate extracurricular facilities (football pitch, volleyball court, handball court, etc.) should be available in secondary schools so that extracurricular activities can be promoted."

Lastly, informant 8 said “...for schools to provide comprehensive extracurricular services, adequate extracurricular facilities must be provided so that active participation of students can be assured. "

Our interviews confirmed that in order to promote extracurricular services in secondary schools, adequate availability of extracurricular services personnel must be ensured. According to informants 1, 2, 3, 5 and 10 "Enough staff should be available to ensure effective provision of extracurricular services in secondary schools. This will make students to be more active in partaking in various activities". Informants 4, 7, 8, 9 and 11 said:

"School's social and sports committee should be comprised of adequate men and women of proven integrity who are to guide students on various activities which include inter-house sports, social club, quiz completion, debate and other related completion".

Similarly, informants 6, 12, 14, 15 and 18 opined that "Since we have various extracurricular activities in secondary schools, adequate personnel should be available to direct and guide students for effective utilization of facilities we have". The foregoing submission is in consonance with the view of informants 13,16, 17 and 19 which said "Honestly, schools need extracurricular service0s personnel to be saddled with responsibility of guiding students when they engage in various extracurricular activities."

The main aim of the present research was to investigate the perceived influence of extracurricular services on students' academic achievement in secondary schools in Kwara State, Nigeria. Thus the discussion of the key findings will be done based on three research questions and objectives of the study.

The first research question of the study was based on contemporary issues on extracurricular services in school. In line with the research question, the first research objective of the study was to know the contemporary issues on extracurricular services in school. Our findings revealed four issues on extracurricular services, they are meaning of extracurricular services, nature of extracurricular services, provision of extracurricular services and perceived influence of extracurricular services on students' academic achievement in secondary schools. Firstly, on what extracurricular services mean, our findings show that majority of the informants explained it as the services that are designed for students' development outside the four walls of the classroom. The foregoing is in tandem with the work of Holloway (2000) who opined that the term extracurricular services refer to any services that school render to students outside the class- 
room. Those services take place outside the regular (compulsory) school curriculum. Similarly, Al- Ansari et al., (2016) and Fujita (2006) found that extracurricular services have to do with the designed programs planned by the school authority for students to enjoy. It is an all-round service which focuses on the cognitive, affective and psychomotor domains of the students. Extracurricular remain a certain service in the school system. It is an activity that gives students' joy outside the classroom because of the elements that are embedded in the extracurricular programs.

Secondly, on the nature of extracurricular services that schools provide for students, our findings indicate that series of extracurricular services are provided for students in schools. In addition to the interviews conducted, observation method was used to complement the interviews conducted. As shown in Table 3, nature of extracurricular services in schools include football, table tennis, volleyball, badminton, quiz completion, social club, debate, etc. The findings corroborate the studies conducted by Ekeke (2014) and Fuji (2006) who concurred that the existence of various extracurricular activities (such as football, volleyball, social club, etc.) are needed to fasttrack students' development and that the types of activities in schools vary because schools have various priorities when it comes to this aspect.

Thirdly, on whether schools provide extracurricular services or not, our findings show that extracurricular services are well provided for students. The findings is in congruent with the research conducted by Edem (2006) and Manebete and Duwa (2015) who found that the provision of extracurricular activities promotes captivating challenges to the students, as well as adding to their activity and novelty of their lesson. Fourthly, concerning whether extracurricular services influence students' academic achievement in secondary schools, our findings reveal that students' who engage in various extracurricular activities in schools perform better in their examinations. The findings is synonymous with the studies conducted by Adeyemo (2010), Bradley et al. (2101) and Courtner-Smith, Sofo, Chouinard and Wallace (2007) who found that extracurricular activities such as baseball, basketball, debating, tennis, chess clubs, drama, student government, choir, yearbook, computer clubs stimulate academic achievement of students. Specifically, they opined that opined that despite the efforts and time the extracurricular activities consume, there is a benefit that is accrued to students who participate in it. The benefit could be in the form of enhanced life skills and fun. In the same vein, Al- Ansari et al., (2016), Ekeke (2014), Trail (2002) and Welk et al. (2010) concluded that overall, the participation of school students in various extracurricular activities positively improved students' academic pursuit and life skills, which include goal-setting, discipline, teamwork, responsibility and accountability. They will find themselves prepared better for post-school activities. There is a high tendency for students to realize that the lessons they acquired outside classroom, whether in sports or social activities, would help them cope with future challenges at their places of work. Additionally, the current finding is also in congruent with developmental framework theory, which theorized that extracurricular activities participation has a positive effect on students' academic performance indirectly as a result of the non-academic and social benefits associated with extracurricular activities participation (Anderman, 2002; Broh, 2002; Fin, 1989; Holland \& Andre, 1987).

The second research question of the study was on factors affecting the provision of extracurricular services in school. In line with the second research question, the second objective of the study was to identify factors affecting provision of extracurricular services in secondary schools. Our findings from interviews reveal that two possible 
factors inhibit the provision of effective extracurricular services; they are non/inadequate availability of extracurricular facilities and non/inadequate availability of extracurricular services personnel. Firstly, on non/inadequate availability of extracurricular facilities, informants complained about inadequate extracurricular facilities in their schools. In order to buttress the foregoing point, evidence from our observation method and other documents attest to the fact that schools lacked adequate extracurricular facilities. As displayed in Table 4, all the 20 selected schools had football pitch and table tennis for students use. Sadly, out of 20 schools, only 8 schools had volleyball court and hall for social events while 4 out of 20 schools had badminton court. Furthermore, 2 out of 20 schools had gymnastics for students use while 5 out of 20 schools had mosque and church for religious activities. The findings is in congruent with the work of Adeyemo (2010) and Ekeke (2014) who concluded that unavailability of extracurricular facilities affect effective implementation of school services. Secondly, concerning non/inadequate availability of extracurricular services personnel, we confirmed that majority of the schools had inadequate personnel to guide students in several extracurricular activities. As shown in Table 5, it indicate that only school $\mathrm{K}$ and school L had 26 and 22 extracurricular services personnel respectively in charge of both sport and other social activities while school C, D, E, P and S had 16, 17, 14, 15 and 15 extracurricular services personnel respectively, which is less than 20 personnel. Also, the remaining schools had less than 15 personnel. We considered the 2 schools with 20 extracurricular services personnel as adequate because they will be able to direct and guide students who engage in various activities, while schools with less than 20 personnel were considered as inadequate. Adeyem (2010) and Okeke (2014) opined that inadequate personnel hindered extracurricular services in education system.
The third research question of the study was on measures that can be used to ensure effective extracurricular services in school. In tandem with the third research question, the aim of the third research objective was to suggest measures that can be used to ensure effective extracurricular services in school. Evidence from the interviews conducted show that two measures were suggested by the informants, they are adequate provision of extracurricular facilities and adequate availability of extracurricular services personnel. On adequate provision of extracurricular facilities, majority of the informants opined that facilities (such as standard football pitch, volleyball court, table tennis, hall centre, etc) should be adequately provided for students in secondary schools so that active participation of students can be guaranteed. The findings are in line with the studies of Bozkus (2013) and Kim and So (2012) who confirmed that extracurricular facilities are important in raising students' skills. Similarly, Gerber (1996), Mash (1992) and Mahoney and Cairns (1997) concluded that availability of extracurricular facilities is necessary for the overall development of students. On adequate availability of extracurricular services personnel, our findings reveal that if adequate personnel are in charge of extracurricular services, it will lead to more participation of students in extracurricular activities. It is believe that if there is adequate personnel in charge, students can be enlightened on the need for participation in extracurricular activities. The foregoing findings correspond with Bozkus (2013) and Ludeman (2002) who opined that the function of extracurricular personnel in school is to educate students on the need to engage in various extracurricular activities. Specifically, they are saddled with the responsibility of organizing sports events, debate and quiz completions for students.

Taken together, it can be said that the present study has successfully provided answers to the three research questions while 
the three research objectives had been achieved. In view of the foregoing, this study made some contributions to the existing body of knowledge in several ways. From practical perspective, our findings will assist schools' principals on the need to understand the important role that extracurricular services play on students' academic achievement. It will also enable them to know the types of extracurricular services that will provided in their schools. In addition, findings will enable the government at all levels (local, state and federal) and other stakeholders in education on how to formulate policy that will ensure effective provision of extracurricular facilities and personnel in secondary schools. From methodological perspective, the use of qualitative approach to investigate the perceived influence of extracurricular services on students' academic achievement is another notable contribution of the present study because literature reviews revealed that there was less research on qualitative study (e.g. Esenturk et al., 2016) investigating the connection between extracurricular services and academic success, hence the use of interviews and observation in this study helped to gain a better understanding of the study phenomenon. From theoretical perspective, our findings on perceived influence of extracurricular services on students' academic achievement validates developmental framework theory, which posit that participation in extracurricular activities improved students' academic success.

\section{Conclusion}

Even though our findings lend credence to the perceived influence of extracurricular services on students' academic achievement in secondary schools but it was observed that there were factors affecting effective provision of these services, namely non/inadequate availability of extracurricular facilities and non/inadequate availability of extracurricular personnel. In the case of our study they were the lacking quantity of the facilities, personnel, and other equipment.

\section{References}

Adeyemo, S. A. (2010). The relationship between students participation in school based extracurricular activities and their achievement in physics. International Journal of Science and Technology Education Research, 1(6), 111-117.

Afiah Binti Sheikh Ismail, N. A. B. (2019). Development of Entrepreneurship Intentions Among School Students in Malaysia. Indonesian Journal on Learning and Advanced Education, l(1), $48-53$. https://doi.org/10.23917/ijolae.v1i1.72 89

Al-Ansari, A., Al-Harbi, F., AbdelAziz, W., AbdelSalam, M., El Tantawi, M. M., \& ElRefae, I. (2016). Factors affecting student participation in extra-curricular activities: A comparison between two Middle Eastern dental schools. The Saudi Dental Journal, 28(1), 36-43.

Anderman, E. M. (2002). School effects on psychological outcomes during adolescence. Journal of Educational Psychology, 94(4), 795-809.

Ary D, Jacobs LC, Razavier A (1997). Introduction to Research in Education. 5th Edition. New York: Harcourt Brace College Publishers.

Bozkus, M. (2013). Sport experience, motivation orientations and academic success.IJAR. Part B, 5(5).

Bradley, C., Nowlan, G., Vajcner, M., Cushon, K., \& Cripps, D. (2012). @ Archer September 2012 Vol. 2, No. 1.

Broh, B. A. (2002). Linking extracurricular programming to academic achievement: Who benefits and why? Sociology of Education, 75(1), 69-95.

Chen, L. J., Fox, K. R., Ku, P. W., \& Wang, C. H. (2012). A longitudinal study of childhood obesity, weight 
status change, and subsequent academic performance in Taiwanese children. Journal of School Health, 82(9), 424-431.

Courtner-Smith, Sofo, Chouinard and Wallace (2007) Extracurricular activities: Beneficial extension of the traditional curriculum or subversion of academic goals? Journal of educational psychology, 84(4), 553.

Creswell, J. (2009). Research design: Qualitative, quantitative, and mixed methods approaches. SAGE Publications, Incorporated.

Donnelly, J. E., Greene, J. L., Gibson, C. A., Sullivan, D. K., Hansen, D. M., Hillman, C. H \& Washburn, R. A. (2013). Physical activity and academic achievement across the curriculum (A+ PAAC): rationale and design of a 3-year, cluster-randomized trial. BMC public health, 13(1), 307.

Edem, D.A. (2006). Introduction to educational administration in Nigeria. Ibadan: Spectrum Books Limited.

Ekeke, J. T. H. (2014). Students'involvement In ExtraCurricular Activities And Their Academic Performance At The Tertiary Level. Atbu Journal of Science, Technology and Education, 1(2), 73-80.

Esenturk, O.K, Demir, G.T, Yilmaz, A and Ilhan, E.L, (2016). Evaluation of the extracurricular sportive activities from the view of physical education teachers. Science, Movement and Health, Volume XVI, Issue 2, 559608.

Fejgin, N. (1994). Participation in high school competitive sports: Subversion of school mission or contribution to academic goals? Sociology of Sport Journal, 11(3), 211-230.

Finn, J. D. (1989). Withdrawing from school. Review of Educational Research, 59(2), 117-142.
Fredricks, J.A., \& Eccles, J. S. (2005). Developmental benefits of extracurricular involvement: Do peer characteristics mediate the link between activities and youth outcomes? Journal of Youth and Adolescence, 34(6), 507-520.

Fujita, K. (2006). The effects of extracurricular activities on the academic performance of junior high students. Undergraduate Research Journal for the Human Sciences, 5(1).

Gerber, S. (1996). Extracurricular activities and academic achievement. Journal of Research and Development in Education, 30(1), 42-50.

Hansen, D. M., Larson, R. W., \& Dworkin, J. B. (2003). What adolescents learn in organized youth activities: A survey of self-reported developmental experiences. Journal of Research on Adolescence, 13(1), 25-55.

Holland, A., \& Andre, T. (1987). Participation in extracurricular activities in secondary school: What is known, what needs to be known? Review of Educational Research, 57(4), 437-466.

Hunt, H. D. (2005). The Effect of extracurricular activities in the educational process: Influence On Academic Outcomes. Sociological Spectrum, 25(4), 417-445. Doi: 10.1080/027321790947171.

Kariyana, I., Maphosa, C., \& Mapuranga, B. (2012). The Influence of Learners' Participation in School Co-curricular Activities on Academic Performance: Assessment of Educators' Perceptions. Journal of Social Sciences, 33(2), 137146.

Kim, S. Y., \& So, W. Y. (2012). The relationship between school performance and the number of physical education classes attended by Korean adolescent students. Journal of Sports Science \& Medicine, 11(2), 226. 
Larson, R. W., Hansen, D. M., \& Moneta, G. (2006). Differing profiles of development experiences across types of organized youth activities. Developmental Psychology, 42(5), 849-863.

Lewis, C. P. (2004). The relation between extracurricular activities with academic and social competencies in school age children: A meta-analysis. Texas A\&M University.

London, R. A., \& Castrechini, S. (2009). A longitudinal examination of the link between youth physical fitness and academic achievement. Journal of School Health, 81(7), 400-408.

Ludeman, R. B. (2002). The role of student affairs and services in Higher Education: A practical manual for developing, implementing, and assessing student affairs programs and services. Online Submission.

Mahoney, J. L., \& Cairns, R.B. (1997). Do extracurricular activities protect against early school dropout?. Developmental Psychology, 33(2), 241-253.

Mahoney, J. L., Cairns, B. D., \& Farmer, T. (2003). Promoting interpersonal competence and educational success through extracurricular activity participation. Journal of Educational Psychology, 95(2), 409-418.

Manabete, S., \& Duwa, S. T. (2015). The Use of School Services in the Management of Technical Colleges in North-East Geo-Political Zone of Nigeria.

Marsh, H. W. (1992). Extracurricular activities: Beneficial extension of the traditional curriculum or subversion of academic goals. Journal of Educational Psychology, 84(4), 553562.

McCaughn, K. P. (1999). The Maturation of High School Students Involved In Extracurricular Activities As Witnessed From A Guidance
Counselor's Perception (Doctoral dissertation, University of WisconsinStout).

Moriana, J.A., Alós, F, Alcalá, R, Pino, M.J., Herruzo, J and Ruiz, R. (2006). Extra-curricular activities and academic performance in secondary students. Electronic Journal of Research in Educational Psychology. ISSN. 1696-2095. No 8, Vol 4 (1) 2006, pp: 35- 46.

Noam, G.G., Biancarosa, G. \& Dechausay, N. (2003). Afterschool education: Approaches to an emerging field. Massachusetts: Harvard University.

Ohiorenuan, O. J. (2008). Extra-Curricular activities and teacher attitude to girlchild education and psycho-motional preparedness. Journal of Soc. Sci, 17(1), 73-82.Orthopsychiatry, 57(3), 316-331.

Osterman, K. F. (2000). Students' need for belonging in the school community. Review of Educational Research, 70(3), 323-367.

Pitts, S. E. (2013). Would you credit it? Navigating the transitions between curricular and extra-curricular learning in university music departments. Arts and Humanities in Higher Education, 12(2-3), 194-203.

Prayitno, H. J., Ngalim, A., Sutopo, A., Rohmadi, M., \& Yuniawan, T. (2018). Power, Orientation, And Strategy of Positive Politeness Used by Children At The Age ff Elementary School With Javanese Cultural Background. Humanus: Jurnal Ilmiah Ilmu-Ilmu Humaniora, 17(2), 164-173.

Rutter, M. (1987). Psychosocial resilience and protective mechanisms. American Journal of Orthopsychiatry, 57(3), 316-331.

Taras, H. (2005). Physical activity and student performance at school. Journal of School Health, 75(6), 214-218.

Trail, K.(2002). Extracurricular sports, and lifelong active living. Journal of 
Teaching in Physical Education, 27(2), 155.

Valentine, J. C., Cooper, H. \& Bettencourt, B. A. (2002). Out-of-school activities and academic achievement: The mediating role of self-beliefs. Educational Psychologist, 37(4), 245256.

Welk, G. J., Jackson, A. W., Morrow Jr, J. R., Haskell, W. H., Meredith, M. D., \& Cooper, K. H. (2010). The association of health-related fitness with indicators of academic performance in Texas schools. Research Quarterly for Exercise and Sport, 81(sup3), S16-S23.

Yıldırım A, Şimşek H. (2013) Sosyal bilimlerde nitel araştırma yöntemleri. Ankara: Seçkin Yayıncılık 